\title{
Fiscal Sustainability of Local Governments in the Visegrad Group Countries
}

\author{
Tomasz Uryszek
}

\section{A B S T R A C T}

Objective: The main goal of the article is to assess the level of fiscal sustainability at the local government level in the Visegrad Group (V4) economies.

Research Design \& Methods: Two different methods of fiscal sustainability measures were used in the article to verify whether the local government deficit is sustainable: estimations of the no-Ponzi conditions, and calculations of the threshold primary balance. The research period covered the years 2001-2016. Data were taken from the Eurostat database.

Findings: Three out of four V4 countries met the initial no-Ponzi condition. The sums of discounted primary balances of their local governments were positive (Poland was the only exception). However, those sums were insufficient to cover the initial debt volume. It was possible in Hungary only. The Ponzi scheme was significantly reduced during the recovery time after the financial crisis of 2008-2009.

Implications \& Recommendations: Generally, all the countries showed the potential to produce primary surpluses at the local level and they have been generally able to stabilise the local debt to GDP ratio. However, these surpluses in the Czech Republic, Slovakia and Poland were insufficient to cover the initial level of debt. Especially Poland should try to generate higher primary local surpluses to avoid the Ponzi scheme and increase the level of fiscal sustainability at the local government level in the future.

Contribution \& Value Added: The originality of this work lies in using the Ponzi scheme and the values of the threshold primary gap to assess the fiscal sustainability of local government levels in the Visegrad Group Economies.

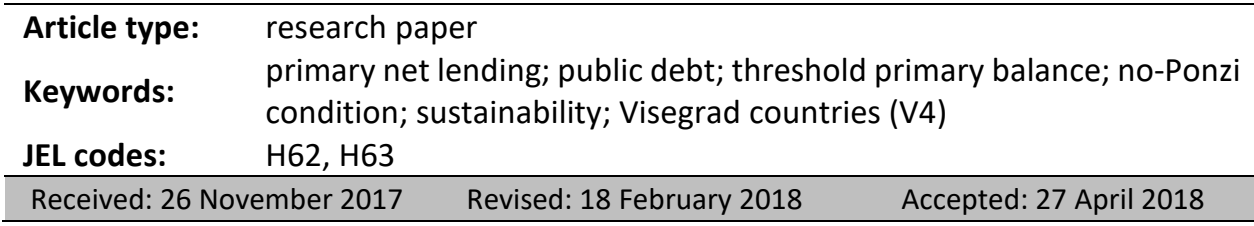

\section{Suggested citation:}

Uryszek, T., (2018). Fiscal Sustainability of Local Governments in the Visegrad Group Countries. Entrepreneurial Business and Economics Review, 6(3), 59-71. https://doi.org/10.15678/EBER.2018.060304 


\section{INTRODUCTION}

Fiscal deficits and public debts are nowadays immanent characteristics of almost all free market economies. Public borrowing seems to be an attractive source of financing for current expenditures not only for the central government but also for local government sectors. This situation can be observed not only in the old EU member states (EU-15), but also among the new EU member states, including Central European economies. Under such circumstances, we should check whether the central government is the only culprit here, or the local sectors also play the Ponzi games.

The main goal of the article is to assess the level of fiscal sustainability of local government sectors in the Visegrad Group (V4) economies. This goal is accompanied by three following hypotheses: (1) local governments in V4 countries have been playing Ponzi games, (2) the Ponzi scheme effects were strengthened by the last financial crisis, (3)the primary net borrowing values prevent from stabilising local debt volumes.

The research period covers the years 2001-2016. The Visegrad countries investigated in the article are the Central European EU member states: the Czech Republic $(\mathrm{CZ})$, Hungary (HU), Poland (PL) and Slovakia (SK).

Two different research methods were used in the article: first, the no-Ponzi conditions were checked. Then, the values of the threshold primary balance were estimated.

The article is organised as follows: the literature review outlines the idea of sustainable fiscal policy and deals with the different methods of fiscal sustainability measures. Then the research methods used in the article as well as data are presented. The next part discusses the empirical results of the study. The most important findings and conclusions are shown in the last part of the article.

\section{LITERATURE REVIEW}

The idea of sustainable fiscal policy dates to the first classical economists, such as Adam Smith, David Hume and David Ricardo (see e.g. Rowley, Shughart, \& Tollison, 2002), and is well developed in the literature (see e.g. Adam, 2015; Potrafke \& Reischmann, 2015; John \& Kurian, 2009; Tsuchiya, 2016; Bohn, 1991). Fiscal sustainability has been already examined in Central and Eastern European countries (see e.g. Krajewski, Mackiewicz, \& Szymańska, 2016), including V4 economies (Sávai, 2016). Sustainable fiscal policy literature deals mostly with the volume of public debt, intertemporal budget constraints and primary (im)balances (see e.g. Neck \& Sturm, 2008; Collard, Habib, \& Rochet, 2015; Legrenzi \& Milas, 2012; Molendowski \& Stanek, 2012).The main assumption of sustainable public finances is that fiscal authorities cannot run Ponzi games (see e.g. Martins-da-Rocha \& Vailakis, 2012; Wigger, 2009; Minea \& Villieu, 2010), meaning that governments cannot use ever-increasing debt. According to the literature review, sustainable fiscal policy excludes situations '....where the government systematically services the cost of existing debt exclusively by issuing new one' (Fan \& Arghyrou, 2013, p. 961). To meet this criterion, the sum of future discounted primary net lending values should cover the volume of outstanding debt. Fiscal sustainability is then based on generating primary budget surpluses and controlling public debt volume (Gevorkyan, 2010, p. 169). This is necessary to reduce growing debt servicing costs. Nowadays, '...trust in fiscal sustainability is key...' (Steger, 2012, p. 62). The main shortcoming of 
this method is the necessity to predict all the future primary balances, which seems to be burdened with a large estimation error. Ex post estimations allow to solve this problem, but in such case a question about the number of observations arises.

Using the idea of present value of budget constraints (see e.g. Chalk \& Hemming, 2000, p. 5), McCallum (1992) argued that public debt should not grow faster than the interest rate. Based on that, Barro (1989) and Kremens (1989) proved that if the economic growth rate is lower than the real interest rate, the public debt to GDP (or the public debt to output) ratio shall be reduced.

Another group of measures are sustainability indicators. The outcomes for these indicators synthetically show how far fiscal policy in a given economy departs from sustainability (Chalk \& Hemming, 2000, p. 7). The indicators focus on public debt volume, economic growth rate, interest rates, and primary budget balances. As they do not need specific prerequisites, they can easily be used in the international comparisons in a given period of time. An important disadvantage of the sustainability indicators is that they are used in an environment without uncertainty (Chalk \& Hemming, 2000, p. 9). Uncertainty should be incorporated into fiscal sustainability analyses to make the study more comprehensive (Bohn, 1995; Hajdenberg \& Romeu, 2010; Tanner \& Samake, 2008; Barnhill Jr. \& Kopits, 2004).

The third group of fiscal sustainability measures are statistical tests and methods (Burnside, 2005). Most of them derive from the Hamilton and Flavin (1986) investigation on the sustainability of US public debt and focuses on the stationarity and cointegration testing of macrofinancial variables: mostly public revenues and expenditures (see e.g. Baglioni \& Cherubini, 1993; Holmes, Otero, \& Panagiotidis, 2010; Afonso \& Jalles, 2016; Trehan \& Walsh, 1988; Chen, 2016; Westerlund \& Prohl, 2010).

The measures of fiscal sustainability of local governments used in practice by fiscal authorities are often country or even local specific. For example, ten different indicators are used in the State of Michigan to monitor the fiscal situation there (Crosby \& Robbins, 2013, p. 529). In the literature the problem of local governments' fiscal sustainability is linked with managing skills of local leaders (Tang et al., 2014; Okubo, 2010), building relevant strategies, intergovernmental fiscal relations (Ji, Ahn \& Chapman, 2015) or spatial planning systems (Wójtowicz, 2015; Wójtowicz, 2016). Fiscal sustainability of the local government level is also relevant to adapted fiscal rules (Moździerz, 2015), level of decentralisation (Maličká, 2016) and institutional framework (Nam \& Parsche, 2001).

\section{MATERIAL AND METHODS}

As many of methods for fiscal sustainability measurement are country and local specific, they can hardly be used for international comparisons. That is why more general methods were used in this article. They can easily be used in the international comparisons.

Estimation of the threshold primary balance (TPB) was the first step of the research. It was used in the form proposed by Blanchard (1990). The TPB can be presented as follows (Blanchard, 1990; Chalk \& Hemming, 2000, p. 8):

where:

$$
\bar{d}=\left(r_{t}-n_{t}\right) b_{t}
$$

$\bar{d}$ - is the primary balance necessary to stabilise the debt to GDP ratio (i.e. the threshold primary balance); 
$r_{t}$ - is the real interest rate on public borrowing in period $\mathrm{t}$;

$n_{t}$ - is a real economic growth rate in period $t$;

$b_{t}$ - is public debt volume to GDP in period $\mathrm{t}$.

The value of $\bar{d}$ greater than the current, actual primary balance $\left(d_{t}\right)$ suggests that the deficit is too large (or the surplus is too small) to stabilise the debt ratio, which means that the fiscal policy is unsustainable.

The no-Ponzi condition was checked as the next step of the empirical research. It can be formally written as follows:

$$
B_{t}=\sum_{j=0}^{\infty} R(t, t+j)^{-1} D_{t+j}
$$

where:

$B_{t}$ - is public debt outstanding in period $t$;

$D_{t}$ - is primary balance (net lending/borrowing less interest on public debt);

$R(t, t+j)=\prod_{k=0}^{j} R_{t+k}$ - is the discount factor applying between periods $t$ and $t+j$,
$R_{t+k}=1+r_{t+k} ;$

$r_{t+k}$ - is the real interest rate on public debt instruments in the period $t+k$, the same for all assets, assuming perfect foresight (O'Connell and Zeldes 1988, p. 434).

The equation 2 formally describes the situation when the sum of all the future, discounted primary balances covers the existing (initial) level of debt. If this criterion is met in a particular economy, the government (the fiscal agent) does not play Ponzi game and the fiscal policy can be considered sustainable.

The formula for fiscal sustainability empirical testing was changed slightly. To avoid the ex ante estimation error, the historical data were used (16 yearly observations form the period 2001-2016). The period seems to be long enough in the light of the average terms to maturity of public borrowing instruments (Eurostat, 2017). The following formula was estimated:

$$
\sum_{j=1}^{16} R(t, t+j)^{-1} D_{t+j} \geq 0
$$

As the debt volumes are large, the initial requirements for the investigated economies were relaxed. It was necessary to check whether the sum of the discounted primary net lending values at the local level for the investigated period was at least positive. If so, one could say that the local government level in the given economy was at least able to pursue the path to repay the existing level of debt.

Then, the second condition for no-Ponzi scheme was estimated. I checked whether the sum of primary net lending values in the given period was able to cover the initial level of debt. It can be formally written as:

$$
\sum_{j=1}^{16} R(t, t+j)^{-1} D_{t+j} \geq B_{0}
$$

where:

$B_{0}$ - is the initial level of local government debt (i.e. form the year 2000), the rest, as in equation 2.

Formal stationarity and cointegration tests were not used in the article. The most popular Dickey-Fuller or Phillips-Perron tests could not be used because of their severe finite sample power and size problems (see e.g. DeJong, Nankveris, Savin, \& Whiteman, 1992).The data sample seemed too small even for the DF-GLS test which is characterised by the best overall performance in small samples (see: Elliott, Rothenberg, \& Stock, 1996). 
It is worth mentioning that tests for cointegration between revenues and expenditures have been widely used in empirical research. However, rejections of sustainability using those tests can be invalid. The intertemporal budget constraint may hold satisfied even if the revenues and expenditures are not cointegrated (Bohn, 2007).

Data for empirical research were taken from Eurostat, and they cover 16 yearly observations between 2001 and 2016 (besides the data on the level of local government debt in 2000 were used as the initial level of debt for Ponzi scheme testing). I used data denominated in EUR, national currency, and in per cent of GDP.

\section{RESULTS AND DISCUSSION}

Performing empirical analyses, one must remember that all the Visegrad Group countries have had some problems with fiscal sustainability at the general government level (Uryszek, 2015a). They are relatively centralised economies, where the fiscal role of local governments has been relatively limited ${ }^{1}$. The results of the research show that fiscal autonomy is scarce there (Uryszek, 2015b). Besides, data analyses show that the share ${ }^{2}$ of the local level in the total public debt sector in all the investigated economies is relatively small (Table 1 ).

Table 1. Local government expenditures' share in general government expenditures in the V4 economies (in \%)

\begin{tabular}{|c|c|c|c|c|}
\hline Year & Czech Rep. & Hungary & Poland & Slovakia \\
\hline 2001 & 22.8 & 24.9 & 31.3 & 6.6 \\
\hline 2002 & 23.7 & 24.9 & 29.7 & 7.8 \\
\hline 2003 & 25.2 & 26.6 & 28.3 & 17.9 \\
\hline 2004 & 27.4 & 25.9 & 29.3 & 16.7 \\
\hline 2005 & 26.0 & 25.6 & 29.6 & 17.0 \\
\hline 2006 & 26.9 & 24.6 & 30.4 & 16.8 \\
\hline 2007 & 26.0 & 23.2 & 30.8 & 16.7 \\
\hline 2008 & 26.1 & 23.3 & 31.7 & 16.6 \\
\hline 2009 & 26.6 & 23.7 & 32.2 & 16.5 \\
\hline 2010 & 26.3 & 25.4 & 32.7 & 17.3 \\
\hline 2011 & 28.5 & 23.0 & 31.9 & 16.6 \\
\hline 2012 & 25.3 & 19.1 & 31.0 & 15.8 \\
\hline 2013 & 26.7 & 15.2 & 30.8 & 15.4 \\
\hline 2014 & 27.3 & 15.9 & 31.6 & 15.9 \\
\hline 2015 & 27.0 & 15.8 & 30.8 & 16.4 \\
\hline 2016 & 25.7 & 12.8 & 31.3 & 15.8 \\
\hline average & 26.1 & 21.9 & 30.8 & 15.4 \\
\hline
\end{tabular}

Source: own calculations based on data from Eurostat.

All the investigated economies can use public borrowing process. However, the levels of the local debt are relatively small (Table 2). The data in Table 2 show that Hungary

\footnotetext{
${ }^{1}$ According to Eurostat, the only self-government level in V4 countries is the local one. The regional levels are not recorded there (which can be moot and controversial, considering e.g. Polish voivodships).

${ }^{2}$ The scope of the local level in the whole public sector is measured here as the share of the local government level expenditure in the total general government expenditure.
} 
was the only V4 country which had not fulfilled the Maastricht criterion relevant to the public debt. The other economies' public debt volumes were significantly lower than $60 \%$ of GDP. On the other hand, the levels of local debt in all the V4 countries were limited and could not play a significant role in the process of public borrowing. The local debt levels should therefore be relatively easy to repay by self-government units. It is, of course, dependent on the level of primary net lending (Figure 1).

It is necessary to check whether the net lending values in the investigated economies were sufficient to stabilise the debt to GDP ratio. The estimations of equation 1 were made and the values of the threshold primary balance (TPB) were calculated to answer this question. In this way it is possible to compare the theoretical, threshold values of primary gaps (or minimal values of surpluses) necessary to stabilise the debt to GDP ratio ('TPB' in Fig. 1 and in Table 3) with the volumes of the actual primary balance ('APB' in Fig. 1 and in Table 3). The outcomes of this comparison are shown in Figure 1.

Table 2. Public debt in V4 economies (in \% of GDP)

\begin{tabular}{|c|c|c|c|c|c|c|c|c|}
\hline \multirow{2}{*}{ Year } & \multicolumn{2}{|c|}{ Czech Republic } & \multicolumn{2}{c|}{ Hungary } & \multicolumn{2}{c|}{ Poland } & \multicolumn{2}{c|}{ Slovakia } \\
\cline { 2 - 9 } & $\begin{array}{c}\text { General } \\
\text { gov. }\end{array}$ & $\begin{array}{c}\text { Local } \\
\text { gov. }\end{array}$ & $\begin{array}{c}\text { General } \\
\text { gov. }\end{array}$ & $\begin{array}{c}\text { Local } \\
\text { gov. }\end{array}$ & $\begin{array}{c}\text { General } \\
\text { gov. }\end{array}$ & $\begin{array}{c}\text { Local } \\
\text { gov. }\end{array}$ & $\begin{array}{c}\text { General } \\
\text { gov. }\end{array}$ & $\begin{array}{c}\text { Local } \\
\text { gov. }\end{array}$ \\
\hline 2001 & 22.8 & 1.6 & 51.4 & 1.1 & 37.3 & 1.3 & 48.3 & 1.3 \\
\hline 2002 & 25.9 & 1.8 & 54.6 & 1.5 & 41.8 & 1.7 & 42.9 & 1.3 \\
\hline 2003 & 28.3 & 2.0 & 57.1 & 1.5 & 46.6 & 1.8 & 41.6 & 1.3 \\
\hline 2004 & 28.5 & 2.3 & 58.0 & 1.6 & 45.0 & 1.8 & 40.6 & 1.2 \\
\hline 2005 & 27.9 & 2.4 & 60.0 & 1.8 & 46.4 & 2.1 & 34.1 & 1.4 \\
\hline 2006 & 27.7 & 2.5 & 64.1 & 2.3 & 46.9 & 2.4 & 31.0 & 1.6 \\
\hline 2007 & 27.5 & 2.4 & 65.0 & 3.0 & 44.2 & 2.2 & 30.1 & 1.7 \\
\hline 2008 & 28.3 & 2.3 & 71.0 & 3.8 & 46.3 & 2.3 & 28.5 & 1.7 \\
\hline 2009 & 33.6 & 2.3 & 77.2 & 4.1 & 49.4 & 3.0 & 36.3 & 2.1 \\
\hline 2010 & 37.4 & 2.5 & 79.7 & 4.6 & 53.1 & 3.8 & 41.2 & 2.4 \\
\hline 2011 & 39.8 & 2.5 & 79.9 & 4.3 & 54.1 & 4.2 & 43.7 & 2.6 \\
\hline 2012 & 44.5 & 2.6 & 77.6 & 3.7 & 53.7 & 4.2 & 52.2 & 2.4 \\
\hline 2013 & 44.9 & 2.8 & 76.0 & 1.5 & 55.7 & 4.3 & 54.7 & 2.2 \\
\hline 2014 & 42.2 & 2.7 & 75.2 & 0.1 & $50.2 *)$ & 4.3 & 53.5 & 2.2 \\
\hline 2015 & 40.0 & 2.4 & 74.7 & 0.2 & 51.1 & 4.2 & 52.3 & 2.3 \\
\hline 2016 & 36.8 & 1.9 & 73.9 & 0.2 & 54.1 & 3.9 & 51.8 & 2.2 \\
\hline average & 32.5 & 2.3 & 67.7 & 2.1 & 47.8 & 2.9 & 43.1 & 1.8 \\
\hline
\end{tabular}

*) The significant decrease in the general government debt in Poland in 2014 was the outcome of the reform of Polish social security system.

Source: own elaboration based on data from Eurostat.

Data analyses show that the most significant differences between the theoretical values of primary net lending necessary to stabilise the debt to GDP ratio and the actual volumes of primary net lending were recorded during the global financial crisis. However, Hungary had strong problems with stabilising the local debt even before the crisis. The Czech Republic and Poland also produced too large primary deficits. It could affect the lack of fiscal sustainability of the local level in these countries. The positive results recorded during the recovery time diminished or even removed that threat. 
The values of the primary gap were calculated as the volume of actual primary balances less the theoretical primary balance volumes necessary to stabilise debt to GDP ratio. The outcomes are presented in Table 3.

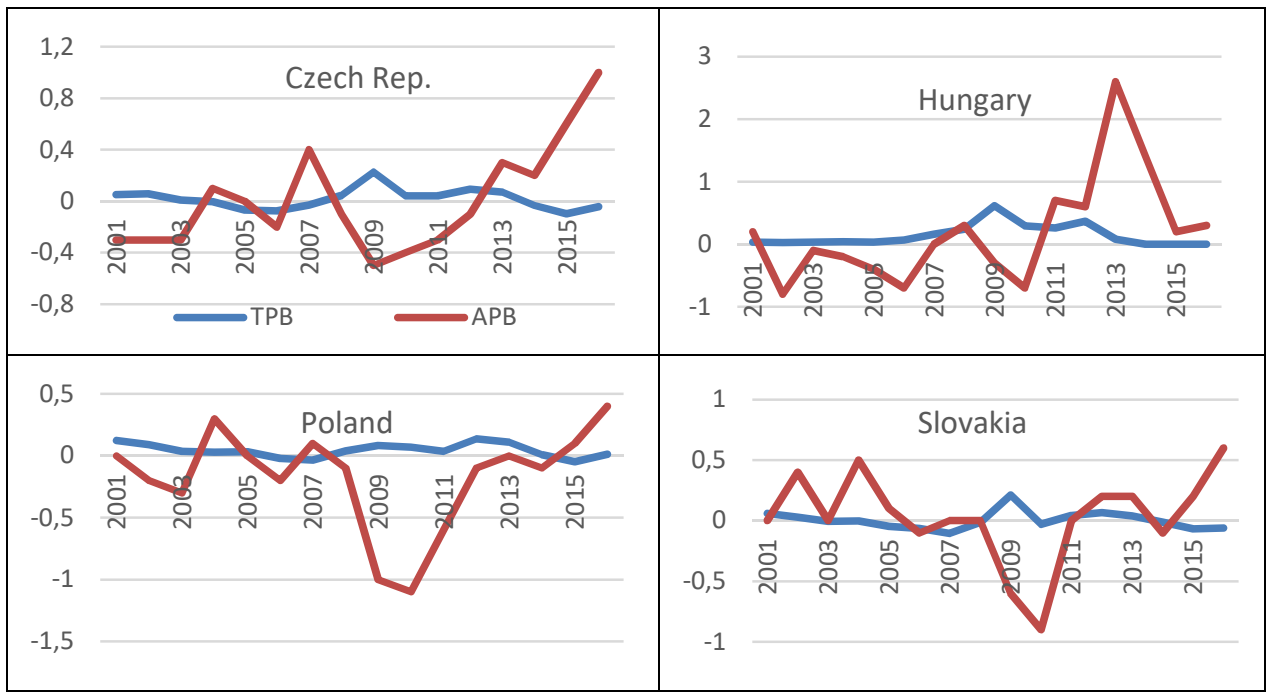

Figure 1. Threshold primary balance (TPB) vs. actual primary balance (APB) values in the local government sectors of V4 countries (in \% of GDP)

Source: own calculations based on data from Eurostat.

The negative values of the primary gap mean that the actual local deficits were too large to stabilise the local debt to GDP ratio. Positive values prove that the actual local net lending values were sufficient to stabilise this ratio. An interesting finding is that the averages of the primary gap for the local governments in all the investigated economies were close to zero (Poland recorded a negative value, but still the gap was relatively small). It means that, on the average, during the last 16 years all V4 countries recorded the net lending values just enough (or almost enough) to stabilise the volume of local debt. In other words, all the countries were able to enter the sustainable fiscal path at the local level.

Using this key finding, it is necessary to check whether these values were high enough to cover the initial level of debt. That is why the next part of the empirical study were the estimations of formulas 3 and 4 . First, I checked whether the sums of the discounted primary net lending values in V4 countries were positive (equation 3). The results are shown in Table 4.

The results show that Poland was the only country which did not pass the initial test of the no-Ponzi scheme at the local government level. The rest of V4 countries passed. The next step was the estimation of equation 4 for the investigated economies. The outcomes are presented in Table 5.

The results show that Hungary was the only country which fulfilled the condition for no-Ponzi scheme for the years 2001-2016. The rest of the V4 countries failed. It means that the Czech Republic, Poland, and Slovakia we unable to repay the initial level of local governments debt (i.e. the debt volume recorded in 2000). In other words, their borrowing needs were higher than their fiscal capacity at the local level. To avoid problems with the 
debt repayment the V4 countries need to tighten their fiscal policies at the local level or give more revenue rising capacity to the local governments.

Table 3. Values of primary gap in in the local government sectors of V4 economies (APB less TPB, in \% of GDP)

\begin{tabular}{|c|c|c|c|c|}
\hline Year & Czech Rep. & Hungary & Poland & Slovakia \\
\hline 2001 & -0.4 & 0.2 & -0.1 & -0.1 \\
\hline 2002 & -0.4 & -0.8 & -0.3 & 0.4 \\
\hline 2003 & -0.3 & -0.1 & -0.3 & 0.0 \\
\hline 2004 & 0.1 & -0.2 & 0.3 & 0.5 \\
\hline 2005 & 0.1 & -0.4 & 0.0 & 0.1 \\
\hline 2006 & -0.1 & -0.8 & -0.2 & 0.0 \\
\hline 2007 & 0.4 & -0.2 & 0.1 & 0.1 \\
\hline 2008 & -0.1 & 0.1 & -0.1 & 0.0 \\
\hline 2009 & -0.7 & -0.9 & -1.1 & -0.8 \\
\hline 2010 & -0.4 & -1.0 & -1.2 & -0.9 \\
\hline 2011 & -0.3 & 0.4 & -0.6 & 0.0 \\
\hline 2012 & -0.2 & 0.2 & -0.2 & 0.1 \\
\hline 2013 & 0.2 & 2.5 & -0.1 & 0.2 \\
\hline 2014 & 0.2 & 1.4 & -0.1 & -0.1 \\
\hline 2015 & 0.7 & 0.2 & 0.1 & 0.3 \\
\hline 2016 & 1.0 & 0.3 & 0.4 & 0.7 \\
\hline average & 0.0 & 0.1 & -0.2 & 0.0 \\
\hline
\end{tabular}

Source: own calculations based on data from Eurostat.

Table 4. No-Ponzi scheme - empirical results for the local government sectors in V4 economies (outcomes for formula 3)

\begin{tabular}{|l|r|r|r|r|}
\hline \multirow{2}{*}{ Country } & \multicolumn{2}{|c|}{ national currency*) } & \multicolumn{2}{c|}{ EUR**) } \\
\cline { 2 - 5 } & \multicolumn{1}{c|}{ million } & unit per capita & million & unit per capita \\
\hline Czech Rep. & 4890.1 & 463.1 & 281.2 & 26.6 \\
\hline Hungary & 300383.8 & 30595.2 & 806.6 & 82.2 \\
\hline Poland & -19463.1 & -512.9 & -4781.6 & -126.0 \\
\hline Slovakia & 119.5 & 22.0 & 47.7 & 8.8 \\
\hline
\end{tabular}

*) Slovakia entered Eurozone in 2009. Slovak koruna was the domestic currency before that date. After that euro is the national currency there.

${ }^{* *}$ ) The data are converted into euro using annual average exchange rates from Eurostat.

Source: own calculations based on data from Eurostat.

The problem of unsustainable fiscal situation of local governments has been presented in the literature. The research methods differ but the results of these studies are mostly consistent with the outcomes of this research: the Polish local finance sector seems to be unsustainable (see e.g. Sroka \& Pogan, 2015). The level of local debt in Poland has been rising and sometimes it is even hidden by the local authorities (Poniatowicz, 2011). Czech Republic also has problems with fiscal sustainability at the local government level (Pospisil, Oancea, \& Dragoescu, 2017). On the other hand, Hungary, after strong crisis, started to stabilise public finance not only at the central but also at the local level (Jankovics, 2016). 
Table 5. No-Ponzi scheme - empirical results for the local government sectors in V4 countries (outcomes for formula 4)

\begin{tabular}{|l|r|r|r|r|}
\hline \multirow{2}{*}{ Country } & \multicolumn{2}{|c|}{ national currency*) } & \multicolumn{2}{c|}{ EUR } \\
\cline { 2 - 5 } & \multicolumn{1}{|c|}{ million } & unit per capita & \multicolumn{1}{c|}{ million } & \multicolumn{1}{c|}{ unit per capita } \\
\hline Czech Rep. & -31194.9 & -2954.1 & -732.3 & -69.3 \\
\hline Hungary & 205168.3 & 20897.2 & 443.5 & 45.2 \\
\hline Poland & -26175.4 & -689.7 & -6469.1 & -170.5 \\
\hline Slovakia & -299.6 & -55.2 & -245.3 & -45.2 \\
\hline
\end{tabular}

*) see note in Table 4.

Source: own elaboration based on data from Eurostat.

\section{CONCLUSIONS}

Analyses show that all the V4 countries are characterised by relatively centralised public finance systems. The scope of the local sector is limited there. The average share of local governments' expenditure in the total public spending of the V4 economies, in the years 2001-2016, was between $15.4 \%$ in Slovakia and $30.8 \%$ in Poland. The level of debt was also low (between $1.8 \%$ of GDP in Slovakia and $2.7 \%$ in Poland, on average). Such a situation should make local debt repayments easy. In other words, the local governments in the V4 economies should have no reason to play Ponzi games. The empirical results show that it is only partly true (as well as the first research hypothesis is). Three out of four countries fulfilled the initial no-Ponzi condition, i.e. the sums of discounted primary balances of their local government levels were positive. Poland was the only exception here.

However, the sums of discounted local governments primary net lending were insufficient to cover the initial debt volume. It was possible in Hungary only. At the same time Hungary was the only V4 country which has not fulfilled the public debt Maastricht criterion. Such a situation suggests that the local level was used by the fiscal authorities to reduce the instability of the whole public sector. The low level of fiscal autonomy of local governments in all the investigated economies does not let these governments to expand expenditures and use more of debt financing. However, the empirical results of no-Ponzi scheme investigation show that the V4 countries did not achieve the full fiscal sustainability at the local level.

The results for the threshold primary balance and the values of the primary gap showed significant imbalances during the last financial crisis. The primary deficit values during crisis were high and at the same time too large to stabilise the local governments debt to GDP ratio, which lends empirical support to the second hypothesis. The Ponzi scheme was then significantly reduced during the recovery time after the crisis. Generally, all the countries showed the potential to produce primary surpluses at the local level and they have been able to stabilise the local debt to GDP ratio. The average values of the primary gap for the whole research period were very close to zero. The large primary deficits recorded in Hungary and Slovakia during the crisis were fully covered by surpluses generated before and after the crisis (and they were almost covered in Poland). Paying a significant interest rate on public debt, Poland should try to generate slightly higher primary local surpluses to avoid the Ponzi games at the self-government level in the future. The third hypothesis in then false. 


\section{REFERENCES}

Adam, A. (2015). Approaches of public finance sustainability taking into account the current economic context. Financial Studies, 19(1), 93-101.

Afonso, A., \& Jalles, J.T. (2016). The elusive character of fiscal sustainability. Applied Economics, 48(28), 2651-2664. https://doi.org/10.1080/00036846.2015.1128074

Baglioni, A., \& Cherubini, U. (1993). Intertemporal budget constraint and public debt sustainability: the case of Italy. Applied Economics, 25(2), 275-283. https://doi.org/10.1080/00036849300000033

Barnhill Jr, T.M., \& Kopits, G. (1998). Assessing fiscal sustainability under uncertainty. Journal of Risk, 6(4), 31-54.

Barro, R J. (1989). The Ricardian approach to budget deficits. Journal of Economic Perspectives, $3(2), 37-54$.

Blanchard, O.J. (1990). Suggestions of a new set of fiscal indicators. OECD Working Papers, 79, 1-34.

Bohn, H. (1991). The sustainability of budget deficits with lump-sum and with income-based taxation. Journal of Money, Credit and Banking, 23(3), 580-604.

Bohn, H. (1995). The sustainability of budget deficits in a stochastic economy. Journal of Money, Credit, and Banking, 27(1), 257-271.

Bohn, H. (2007). Are stationarity and cointegration restrictions really necessary for the intertemporal budget constraint?. Journal of Monetary Economics, 54, 1837-1847.

Burnside, C. (Ed.). 2005. Fiscal sustainability in theory and practice. A handbook. Washington, D.C.: The World Bank.

Chalk, N., \& Hemming, R. (2000). Assessing fiscal sustainability in theory and practice. IMF Working Papers, WP/00/81, 1-27.

Chen, P-F. (2016). US fiscal sustainability and the causality relationship between government expenditures and revenues: a new approach based on quantile cointegration. Fiscal Studies, 37(2), 301-320.

Collard, F., Habib, M., \& Rochet, J-C. (2015). Sovereign debt sustainability in advanced economies. Journal of the European Economic Association, 13(3), 381-420. https://doi.org/10.1111/jeea.12135

Crosby, A., \& Robbins, D. (2013). Mission impossible: monitoring municipal fiscal sustainability and stress in Michigan, Journal of Public Budgeting. Accounting \& Financial Management, 25(3), 522-555.

DeJong, D.N., Nankveris, J.C., Savin, N.E., \& Whiteman, C.H. (1992). The power problem of unit root tests in time series with autoregressive errors. Journal of Econometrics, 53, 323-343.

Elliott, G., Rothenberg, T., \& Stock, J. (1996). Efficient tests for an autoregressive unit root. Econometrica, 64(4), 813-836.

Eurostat. (2017). Structure of government debt. Statistics Explained. Retrieved on February 17, 2018 from http://ec.europa.eu/eurostat/statistics-explained/index.php/Structure_of_government_debt

Fan, J., \& Arghyrou, M.G. (2013). UK Fiscal Policy Sustainability, 1955-2006. The Manchester School, 81(6), 961-991.

Gevorkyan, A.V. (2010). Fiscal policy in transition economies: opportunities for sustainable development. Proceedings of the Northeast Business and Economics Association, 169-174.

Hajdenberg, A., \& Romeu, R. (2010). Parameter estimate uncertainty in probabilistic debt sustainability analysis. IMF Staff Papers, 57(1), 61-83. https://doi.org/10.1057/imfsp.2009.25

Holmes, M.J., Otero, J., \& Panagiotidis, T. (2010). Are EU budget deficits stationary?. Empirical Economics, 38(3), 767-778.

Jankovics, L. (2016). Local government finances in Hungary: from the culprit of fiscal slippages to a source of stability?. Society \& Economy, 38(4), 455-478. 
Ji, H., Ahn, J., \& Chapman, J. (2016). The role of intergovernmental aid in defining fiscal sustainability at the sub-national level. Urban Studies, 53(14), 3063-3081. https://doi.org/10.1177/0042098015601600

John, J., \& Kurian, N.J. (2009). Sub-national fiscal sustainability in a globalised setting. Cambridge, UK: Cambridge Scholars Publishing.

Krajewski, P., Mackiewicz, M., \& Szymańska, A. (2016). Fiscal Sustainability in Central and Eastern European Countries - a Post-Crisis Assessment. Prague Economic Papers, 25(2), 175-188. https://doi.org/10.18267/j.pep.553

Kremers, J.J.M. (1989). U.S. Federal Indebtedness and the Conduct of Fiscal Policy. Journal of Monetary Economics, 23(2), 219-238.

Legrenzi, G. \& Milas, C. (2012). Nonlinearities and the sustainability of the government's intertemporal budget constraint. Economic Inquiry, 50(4), 988-999. https://doi.org/10.1111/j.14657295.2011.00402.x

Maličká, L. (2016). Searching for fiscal decentralization constraining effect on local expenditure: case of Visegrad countries. Scientific Papers of the University of Pardubice. Series D. Faculty of Economics \& Administration, 23(38), 68-80.

Martins-da-Rocha, V-F., \& Vailakis, Y. (2012). On Ponzi schemes in infinite horizon collateralized economies with default penalties. Annals of Finance, 8(4), 455-488. https://doi.org/10.1007/s10436-012-0209-y

McCallum B.T. (1992). Are Bond-financed Deficits Inflationary?: A Ricardian Analysis. Journal of Political Economy, 92(1), 123-134.

Minea, A., \& Villieu, P. (2010). Endogenous growth, government debt and budgetary regimes: A corrigendum. Journal of Macroeconomics, 32(2), 709-711. https://doi.org/10.1016/S01640704(00)00136-1

Molendowski, E., \& Stanek, P. (2012). Globalny kryzys finansowo-gospodarczy i strefy euro a sytuacja fiskalna nowych państw członkowskich (UE-10), (Recent financial and economic crisis and its impact on the fiscal sustainability the new member states [EU-10]). Acta Universitatis Lodziensis Folia Oeconomica, 273, 267-284.

Moździerz, A. (2015). Strengthening the Post-crisis Fiscal Rules - the Case of Spain, Slovakia and Sweden. Equilibrium. Quarterly Journal of Economics and Economic Policy, 10(2), 31-52.

Nam, C.W., \& Parsche, R. (2001). Municipal Finance in Poland, the Slovak Republic, the Czech Republic and Hungary: Institutional Framework and Recent Development. MOST: Economic Policy in Transitional Economies, 11(2), 143-164.

Neck, R., \& Sturm, J-E. (2008). Sustainability of public debt. Cambridge, MA: Massachusetts Institute of Technology.

O'Connell, S.A., \& Zeldes, S.P. (1988). Rational Ponzi games. International Economic Review, 29(3), 431-450.

Okubo, D. (2010). Fiscal sustainability and local government. National Civic Review, 99(4), 34-39. https://doi.org/10.1002/ncr.20035

Poniatowicz, M. (2011). Ukrywanie długu jednostek samorządu terytorialnego w Polsce - problem realny czy marginalny? (Concealment of local authority debt in Poland - a real problem or a marginal one?). Ekonomiczne Problemy Usług, 76, 203-216.

Pospisil, R., Oancea, B., \& Dragoescu, R.M. (2017). The Current Sustainability of Local Bugets in the Czech Republic, 17th International Conference - Globalization and its Socio-Economic Consequences, University of Zilina, Slovakia. 
Potrafke, N., \& Reischmann, M. (2015). Fiscal transfers and fiscal sustainability. Journal of Money, Credit and Banking, 47(5), 975-1005.

Rowley, C.K., Shughart, W.F., \& Tollison, R.D. (Eds.) (2002). The Economics of Budget Deficits, Cheltenham, UK: Edward Elgar.

Sávai, M. (2016). Short-term Fiscal Sustainability of V4 Countries. European Financial and Accounting Journal, 2016(3), 169-182.

Sroka, W., \& Pogan, P. (2015). Nierównowaga finansów samorządowych a poziom zrównoważenia rozwoju gmin wiejskich województwa małopolskiego, (Imbalance of self-government finance versus level of sustainable development of the rural communes in Małopolska province). Stworarzyszenie Ekonomistów Rolnictwa i Agrobiznesu. Roczniki Naukowe, 17(4), 288-294.

Steger, G. (2012). Redirecting public finance towards a sustainable path. OECD Journal on Budgeting, 2, 61-67.

Yan Tang, S., Rubio-Cortés, G., Callahan, R., Pisano, M., \& McGrath, M. (2014). Key Findings on Fiscal Sustainability for Local Governments in Southern California. National Civic Review, 103(3), 3-13. https://doi.org/10.1002/ncr.21201

Tanner, E., \& Samake, I. (2008). Probabilistic sustainability of public debt: a vector autoregression approach for Brazil, Mexico and Turkey. IMF Staff Papers, 55(1), 149-182. https://doi.org/10.1057/palgrave.imfsp.9450029

Trehan, B., \& Walsh, C.E. (1988). Common trends, the government's budget constraint, and revenue smoothing. Journal of Economic Dynamics and Control, 12(2/3), 425-444.

Tsuchiya, Y. (2016). Directional analysis of fiscal sustainability: revisiting Domar's debt sustainability condition. International Review of Economics and Finance, 41, 189-201. https://doi.org/10.1016/j.iref.2015.08.012

Uryszek, T. (2015a). Long-term sustainability of public finance in the Central and Eastern EU member states. Comparative Economic Research, 18(4), 47-61. https://doi.org/10.1515/cer-2015-0028

Uryszek, T. (2015b). Samodzielność finansowa jednostek samorządu terytorialnego. Polska na tle wybranych krajów Unii Europejskiej (Financial autonomy of local and regional governments. Poland in the light of the selected EU economies). Finanse Komunalne, 12, 5-14.

Westerlund, J., \& Prohl, S. (2010). Panel cointegration tests of the sustainability hypothesis in rich OECD countries. Applied Economics, 42(11), 1355-1364.

Wigger, B.U. (2009). A note on public debt, tax-exempt bonds, and Ponzi games. Journal of Macroeconomics, 31(3), 492-499. https://doi.org/10.1016/j.jmacro.2008.07.003

Wójtowicz, K. (2015). System planowania przestrzennego a stabilność fiskalna polskich gmin (Spatial planning system vs. fiscal sustainability of Polish local governments). Research Papers of the Wroclaw University of Economics / Prace Naukowe Uniwersytetu Ekonomicznego we Wroclawiu, 404, 311-327. https://doi.org/10.15611/pn.2015.404.21

Wójtowicz, K. (2016). Prognozowanie skutków finansowych miejscowych planów zagospodarowania przestrzennego a problem zapewnienia stabilności fiskalnej gmin w Polsce (Forecasting of fiscal consequences of local spatial plans vs. the problem of achieving fiscal sustainability of local governments in Poland). Research Papers of the Wroclaw University of Economics / Prace Naukowe Uniwersytetu Ekonomicznego we Wroclawiu, 432, 203-211. https://doi.org/10.15611/pn.2016.432.18 


\section{Author}

\section{Tomasz Uryszek}

Assistant Professor of the University of Lodz. His research interests include public funds management, public debt, fiscal deficit and fiscal sustainability.

Correspondence to: Tomasz Uryszek, PhD, Department of Banking, Institute of Finance, Faculty of Economics and Sociology, University of Lodz, Rewolucji 1905 r. No. 39, 90-214 Lodz, Poland, e-mail: tomasz.uryszek@uni.lodz.pl

\section{Acknowledgements and Financial Disclosure}

The author would like to thank the anonymous referees for their useful comments, which allowed to increase the value of this article.

\section{Copyright and License}

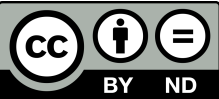

This article is published under the terms of the Creative Commons

Attribution - NoDerivs (CC BY-ND 4.0) License

http://creativecommons.org/licenses/by-nd/4.0/

Published by the Centre for Strategic and International Entrepreneurship - Krakow, Poland 
